\title{
Resistance to Quinone Outside Inhibitor Fungicides Conferred by the G143A Mutation in Cercospora sojina (Causal Agent of Frogeye Leaf Spot) Isolates from South Dakota Soybean Fields
}

\author{
Febina M. Mathew, ${ }^{1}$ Emmanuel Byamukama, ${ }^{1}$ Danilo L. Neves, ${ }^{2}$ and Carl A. Bradley ${ }^{2, t}$ \\ ${ }^{1}$ Department of Agronomy, Horticulture, and Plant Science, South Dakota State University, Brookings, SD 57007 \\ ${ }^{2}$ Department of Plant Pathology, University of Kentucky Research and Education Center, Princeton, KY 42445 \\ Accepted for publication 16 April 2019. \\ Keywords: fungicide resistance, mycology, field crops, Qol
}

Frogeye leaf spot of soybean (Glycine max), caused by Cercospora sojina, is a yield-limiting disease in the United States. From 2010 to 2014, frogeye leaf spot caused estimated annual losses ranging from 101,432 to 493,880 metric tons in the United States and Ontario, Canada (Allen et al. 2017). When quinone outside inhibitor (QoI) fungicides first became registered for use on soybean in the early 2000s in the United States, they were highly effective in managing frogeye leaf spot, but in 2010, QoI-resistant C. sojina isolates were detected for the first time in a Tennessee soybean field (Zhang et al. 2012). These QoI-resistant isolates from Tennessee were found to have the G143A mutation that confers resistance to QoI fungicides (Zeng et al. 2015). Since then, QoIresistant $C$. sojina isolates with the G143A mutation have become widespread across U.S. soybean production regions and have been detected in 240 counties and parishes across 14 states from 2010 to 2017 (Zhang et al. 2018).

In September 2018, soybean leaves exhibiting frogeye leaf spot symptoms (circular to irregular-shaped light-tan to gray lesions with purple margins) were collected from soybean fields in Brookings, Davison, Lincoln, Union, and Yankton Counties in South Dakota, and $C$. sojina isolates were obtained. To isolate $C$. sojina, symptomatic leaves were placed in closed plastic boxes containing moist paper towels to serve as moist chambers, which were left on the lab bench for $24 \mathrm{~h}$ to encourage sporulation. Using a micropipette, sterile water was placed onto sporulating lesions, drawn back up to collect conidia, and deposited onto water agar (15 g/liter). The conidial suspensions were spread across water agar with a sterile glass rod and were incubated at room temperature (approximately $23^{\circ} \mathrm{C}$ ). After 12 to $18 \mathrm{~h}$, a single germinating conidium was selected and transferred to soybean stem lima bean agar (Phillips and Boerma 1981). The plates were incubated for 7 days under 12-h light/dark at room temperature. In total, 41 single-spore isolates were obtained and were stored in $15 \%$ glycerol solution in sterile cryogenic tubes at $-80^{\circ} \mathrm{C}$.

${ }^{\dagger}$ Corresponding author: C. A. Bradley; E-mail: carl.bradley@uky.edu

Funding: This work was supported by the United Soybean Board and the South Dakota Soybean Research and Promotion Council.

The author(s) declare no conflict of interest.

(C) 2019 The American Phytopathological Society
A discriminatory dose assay, using $0.1 \mu \mathrm{g} / \mathrm{ml}$ of azoxystrobin and $60 \mu \mathrm{g} / \mathrm{ml}$ of salicylhydroxamic acid, was used to differentiate QoI-resistant and QoI-sensitive isolates (Zhang et al. 2018). Conidia that germinated on the discriminatory dose of azoxystrobin were considered to be resistant to QoI fungicides. Isolates were also tested for the presence of the G143A mutation using a polymerase chain reaction (PCR) assay reported by Zeng et al. (2015). For both the discriminatory dose assay and the PCR assay, known QoIsensitive and QoI-resistant isolates of $C$. sojina were included as negative and positive controls.

Results of the discriminatory dose assay and the PCR assay showed that 29 out of the 41 South Dakota $C$. sojina isolates were resistant to QoI fungicides. The QoI-resistant isolates came from Davison (four out of six isolates), Lincoln (three out of three isolates), Union (three out of three isolates), and Yankton (19 out of 24 isolates) Counties. No QoI-resistant isolates were detected from Brookings County (zero out of five isolates).

This is the first report of QoI-resistant $C$. sojina isolates occurring in South Dakota. Considering that South Dakota ranked eighth in the United States for soybean production in 2018 with approximately 6.99 million metric tons produced, this finding warrants the need for additional surveys to determine the prevalence of QoI fungicide-resistant $C$. sojina isolates in South Dakota where QoIresistant isolates have not yet been detected. This finding expands the geographical distribution of QoI-resistant $C$. sojina isolates in the United States, with Iowa being the only adjacent state to South Dakota having reported QoI-resistant isolates (Zhang et al. 2018). This finding is interesting in that only $3 \%$ of soybean hectares grown in South Dakota were estimated to have been sprayed with a foliar fungicide in 2017 according to the U.S. Department of Agriculture National Agricultural Statistics Service (https://quickstats.nass. usda.gov/). Soybean growers in South Dakota should consider managing frogeye leaf spot by planting resistant soybean cultivars, rotating soybean with nonhost crops, tilling to speed up decomposition of inoculum, and spraying fungicides that contain active ingredients from chemistry classes other than the QoI class.

\section{Literature Cited}

Allen, T. W., Bradley, C. A., Sisson, A. J., Byamukama, E., Chilvers, M. I., Coker, C. M., Collins, A. A., Damicone, J. P., Dorrance, A. E., Dufault, N. S., Esker, P. D., Faske, T. R., Giesler, L. J., Grybauskas, A. P., Hershman, D. E., Hollier, C. A., Isakeit, T., Jardine, D. J., Kelly, H., Kemerait, R. C., Kleczewski, N. M., Koenning, S. R., Kurle, J. E., Malvick, D. K., Markell, 
S. G., Mehl, H. L., Mueller, D. S., Mueller, J. D., Mulrooney, R. P., Nelson, B. D., Newman, M. A., Osborne, L., Overstreet, C., Padgett, G. B., Phipps, P. M., Price, P. P., Sikora, E. J., Smith, D. L., Spurlock, T. N., Tande, C. A., Tenuta, A. U., Wise, K. A., and Wrather, J. A. 2017. Soybean yield loss estimates due to diseases in the United States and Ontario, Canada from 2010 to 2014. Plant Health Prog. 18:19-27.

Phillips, D. V., and Boerma, H. R. 1981. Cercospora sojina race 5: A threat to soybeans in the southeastern United States. Phytopathology 71:334-336.

Zeng, F., Arnao, E., Zhang, G., Olaya, G., Wullschleger, J., Sierotzki, H., Ming, R., Bluhm, B. H., Bond, J. P., Fakhoury, A. M., and Bradley, C. A. 2015. Characterization of quinone outside inhibitor fungicide resistance in $\mathrm{Cer}$ cospora sojina and development of diagnostic tools for its identification. Plant Dis. 99:544-550.
Zhang, G., Allen, T. W., Bond, J. P., Fakhoury, A. M., Dorrance, A. E., Weber, L., Faske, T. R., Geisler, L., Hershman, D., Neves, D., Hollier, C., Kelly, H. M., Newman, M. A., Kleczewski, N. M., Koenning, S. R., Thiessen, L. D., Mehl, H. L., Zhou, T., Meyer, M. D., Mueller, D. S., Kandel, Y. R., Price, P. P., III, Rupe, J. C., Sikora, E. J., Standish, J. R., Tomaso-Peterson, M., Wise, K. A., and Bradley, C. A. 2018. Widespread occurrence of quinone outside inhibitor fungicide-resistant isolates of Cercospora sojina, causal agent of frogeye leaf spot of soybean, in the United States. Plant Health Prog. 19:295-302.

Zhang, G. R., Newman, M. A., and Bradley, C. A. 2012. First report of the soybean frogeye leaf spot fungus (Cercospora sojina) resistant to quinone outside inhibitor fungicides in North America. Plant Dis. 96:767. 